\title{
Anti-tumor effects of immunotherapeutic peptide on the treatment of hepatocellular carcinoma with $\mathrm{HBc}$ carrier
}

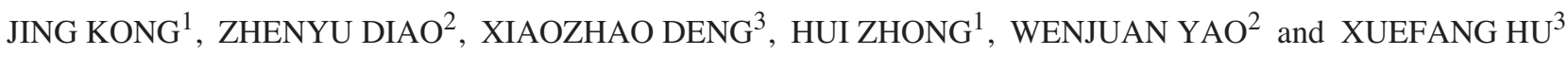 \\ ${ }^{1}$ College of Biological Science and Technology, China Pharmaceutical University, Nanjing 210009; \\ ${ }^{2}$ College of Life Science, Nanjing Normal University, Nanjing 210097; ${ }^{3}$ Huadong Research Institute \\ for Medicine and Biotechniques, Nanjing 210002, P.R. China
}

Received February 24, 2007; Accepted March 27, 2007

\begin{abstract}
Hepatocellular carcinoma (HCC) is a leading cause of cancer-related death. Tumor specific cellular and humoral immunotherapy may be a viable approach for the treatment of HCC. This study investigated specific inhibitory and cytotoxic effects on hepatocellular carcinoma (HCC) induced by the peptide, designated $\mathrm{HBc} \Delta-5 \mathrm{~L}$, using $\mathrm{HBc}$ carrier with multiple $\mathrm{T}$ cell and $\mathrm{B}$ cell sequence insertions. We developed the $\operatorname{HBc} \Delta$ carrier containing insertions of multiple CTL and $\mathrm{T}$ helper (Th) epitopes, which were selected from HCC tumor associated antigens (TAAs) including $\alpha$ fetoprotein (AFP), melanoma antigen gene (MAGE) and telomerase reverse transcriptase (TERT) antigen, and ligands for EGFR and IGFR, designated $\mathrm{HBc} \Delta-5 \mathrm{~L}$. LDH release assay and IFN- $\gamma$ ELISPOT assay were carried to determine whether $\mathrm{HBc} \Delta-5 \mathrm{~L}$ could induce specific cytotoxicity in peripheral blood mononuclear cells (PBMC) of HCC donors. The levels of antibodies and inhibitory effects of sera of immunized mice against $\mathrm{HBc} \Delta-5 \mathrm{~L}$ were also identified. $\mathrm{LDH}$ release assay revealed that PBMC from $\mathrm{HCC}$ donor group $(\mathrm{n}=8)$ stimulated with $\mathrm{HBc} \Delta-5 \mathrm{~L}$ could specifically kill target tumor cells and specific lysis was $62.7 \%$ (E:T=60:1). ELISPOT assay showed a significant increase in secretion of IFN- $\gamma$ from PBMC of HCC donor group in response to $\operatorname{HBc} \Delta-5 \mathrm{~L}$. Further, high specific antibody titers were elicited in immunized mice and revealed $42 \%$ inhibition of cell growth. These results indicated that inhibitory and cytotoxic effects could be efficiently induced by $\mathrm{HBc} \Delta-5 \mathrm{~L}$ recombinant particles using $\operatorname{HBc} \Delta$ as carrier and suggested that it could be important in design of immunotherapeutic approaches.
\end{abstract}

Correspondence to: Dr Xiao-Zhao Deng, Huadong Research Institute for Medicine and Biotechniques, 293 Zhong-shan East Road, Nanjing 210002, P.R. China

E-mail: cpukj@163.com; dengxiaozhao1002@vip.sina.com

Key words: HBc particles, tumor associated antigen, epitope, growth factor receptor, ligand, cellular immunity, humoral immunity, hepatocellular carcinoma

\section{Introduction}

With an estimated incidence of about one million cases, hepatocellular carcinoma (HCC) is one of the most common cancers worldwide. The prevalence is $>100$ per million population in Southeast Asia, especially in China where hepatitis B virus infection is endemic, and some places in Africa, whereas in Europe and North America it is estimated as 2-4 per million population $(1,2)$. Curative treatment can be offered only in a minority of cases and is limited to surgical resection or transplant, which are effective only in localized tumors (3). Alternative options such as percutaneous intratumoral ethanol injection, transarterial chemoembolization and radiofrequency thermal ablation are reserved for palliation $(3,4)$. Therefore, identifying and establishing alternative approaches for treatment of HCC is quiet a challenge and of high interest. One approach that has shown promising results in other tumors is immunotherapy (5). Also in HCC, induction of specific cellular and humoral immunity are the focus of recent anti-tumor immunotherapy.

We investigated the possibility of truncated hepatitis B virus core $(\mathrm{HBc} \Delta)($ aa 1-149) as carrier for the construction of active peptide eliciting specific inhibitory and cytotoxic effects on HCC. It is well known that the carboxy-terminal region (aa 150-183) of the $\mathrm{HBc}$ responsible for nucleic acid binding can be deleted without disturbing the formation of HBc particles (6). In addition, we have successfully constructed a DNA vaccine against Taenia solium cysticercosis using $\mathrm{HBc} \Delta$ as carrier (7). $\mathrm{HBc} \Delta$ carrier is capable of ensuring a high level of $\mathrm{B}$ cell and $\mathrm{T}$ cell immunogenicity to foreign epitopes (8). In addition to the ability of the $\mathrm{HBc} \Delta$ carrier moiety to provide $\mathrm{T}$ cell help to inserted sequences, the $\mathrm{HBc} \Delta$ capsid mediates the T-cell-independent character of the humoral response to inserted epitopes, due to the high degree of repetitiveness of the epitopes and the proper spacing between them (9).

Recent progress in the molecular identification of tumor associated antigens (TAAs) and understanding the mechanisms of TAA presentation and their recognition by $\mathrm{T}$ lymphocytes provide a valuable and promising basis for immunotherapeutic interventions. Based on the above, we chose $\mathrm{HBc} \Delta$ particles as carrier with internal and $\mathrm{C}$-terminal insertions for engineering a synthetic multiple active peptide immunogen 
including the following HCC TAA epitopes and growth factor receptor ligands.

$\alpha$-fetoprotein (AFP) is found in $\sim 80 \%$ of the $\mathrm{HCC}$ and is a potential target for immunotherapy in HCC. Both the murine and human T-cell repertoires can recognize AFP-derived epitopes in the context of the MHC I (10). We determined the identity of AFP-derived epitopes, presented in the context of HLA-A*0201, that could be recognized by the human $T$

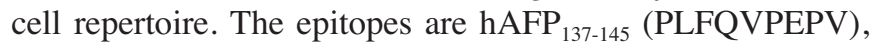
hAFP $_{158-166}$ (FMNKFIYEI), hAFP ${ }_{325-334}$ (GLSPNLNRFL) and hAFP $_{542-550}$ (GVALQTMKQ) which can consistently elicit cytokine production and cytotoxicity (11).

Melanoma antigen gene-A (MAGE-A) is a multi-gene family that consists of 12 homologous genes (MAGE-A1 to -A12). Individual MAGE-A expression varies from one tumor type to the other, but overall the large majority of tumors expresses at least one MAGE-A. Zerbini et al (12) reported the presence of tumor Ag-specific $\mathrm{CD}^{+} \mathrm{T}$ cells (specific for MAGE-A1 and -A3) in HCC. So we chose a CTL epitope (p248V9:YLEYRQVPV) which could generate an HLAA*0201-restricted CTL response and shared by MAGE-A1, -A2, -A3, -A4, -A6, -A10 and -A12 tumor antigens (13). To achieve a better result, we also chose another HLA-A1 restricted CTL epitope MAGE 161-169 (EADPTGHSY) (14).

Human telomerase reverse transcriptase (TERT) is a widely expressed TAA. Furthermore, its expression has been directly linked to tumor development such that inhibition of telomerase in telomerase-positive human tumors leads to growth arrest $(15,16)$. So we chose DR4, DR11 and DR15

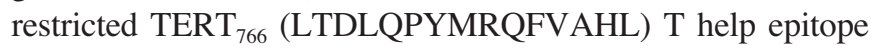
(17) and TERT-derived HLA-A3 restricted CTL epitope (K973:KLFGVLRLK) (18).

It is evident that the level of growth factor expression is a determinant of tumor proliferation, invasiveness, and angiogenesis, and relates adversely to prognosis. Therefore, blockade of autocrine loops of growth factor is a rational strategy for the treatment of many malignancies $(19,20)$. Ren et al $(21,22)$, reported that E5 (EPFRS PDLAL ETYG) (the ligand for type I and II insulin-like growth factor receptors) and GE7 (NPVVG YIGER PQYRD L) (the ligand for epidermal growth factor receptor) and tested their roles in targeting tumor cells that overexpress them. In this report, we chose E5 and GE7 to induce the anti-tumor humoral immunity.

Therefore, to be effective, they should preferably be used in combination for the therapy of HCC. And because tumor cells might lose one or more TAA epitopes, we chose multiple epitopes of each antigen to increase the possibility of targeting. We described the engineering of a synthetic multiple active peptide immunogen and investigated its anti-tumor effects through induction of cellular and humoral immunity against HCC cells.

\section{Materials and methods}

Preparation of peripheral blood mononuclear cells from healthy volunteers and cancer patients. 8 healthy volunteers (6 male and 2 female, mean age 32.5-years) were enrolled in this study along with $8 \mathrm{HBV}$ negative HCC patients (6 male and 2 female, mean age 49-years) were final diagnosis using operation pathology, cell puncture, symptom, physical signs,
AFP, enhance CT, magnetic resonance imaging (MRI) and arteriography. Patients were classified as 2 stage I, 5 stage II and 1 stage III. Informed consent was obtained from all patients and donors. Peripheral blood mononuclear cells (PBMC) were isolated from donors by Ficoll-Hypaque density gradient centrifugation.

Animals. Six-week-old female BALB/c mice were used in the experiment. They were kept under specific pathogen-free conditions with free access to a standard commercial diet. And all animal procedures were performed according to approved protocols and in accordance with recommendations for proper care and use of laboratory animals.

Cell culture. Human HCC cell line SMMC-7721 cells (AFP+, MAGE-A ${ }^{+}$, TERT $\left.^{+}\right)$(23-25) and human normal liver cells L-02 were purchased from Nanjing Keygentec Co. (China) and cultured at $37^{\circ} \mathrm{C}$ in a humidified $5 \% \mathrm{CO}_{2}$ atmosphere in RPMI-1640 medium (Sigma, St. Louis, MO, USA) supplemented with $10 \%(\mathrm{v} / \mathrm{v})$ fetal calf serum (FCS), 100 units $/ \mathrm{ml}$ of penicillin and $100 \mu \mathrm{g} / \mathrm{ml}$ of streptomycin.

Construction, expression and purification of four recombinant proteins in E. coli cells. $\mathrm{HBc} \Delta \mathrm{DNA}$ was isolated from serum of one chronic active hepatitis patient. The primers used for PCR were designed according to the HBV sequence subtype adw2 (GenBank no. AY707087). P1: 5' GA TAT

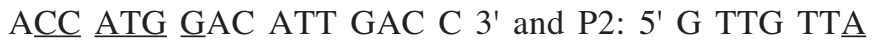
AGC TTA AAC AAC AGT AGT TTC CGG AAG 3'. P1 and P2 and two other primers P3: 5' TGG GGA GAA TTC

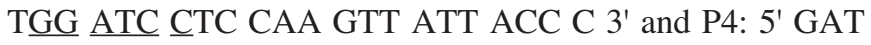
CCA GAA TTC TCC CCA GCA TCT AGG GAT CTA G $3^{\prime}$ were used to introduce $B a m \mathrm{HI}$ and EcoRI restricted sites between aa 78-79 of $\mathrm{HBc} \Delta$. The fragment of epitopes of MAGE and TERT and two ligands and another fragment of epitopes of AFP were inserted into the MIR and C-terminus of $\mathrm{HBc} \Delta$ carrier, respectively, designated $\mathrm{HBc} \Delta-5 \mathrm{~L}$. Then three fragments of epitopes of MAGE, TERT and AFP were inserted into the same sites of $\mathrm{HBc} \Delta-5 \mathrm{~L}$, respectively, termed $\mathrm{HBc} \Delta$-MAGE, HBc $\Delta$-TERT and HBc $\Delta$-AFP. The schemes of four recombinant proteins are illustrated in Fig. 1. The expression and purification of recombinant proteins were generated as previously described (7).

Electron microscopy. To detect the particle formation ability of purified protein $(\mathrm{HBc} \Delta-5 \mathrm{~L}), 0.4 \mathrm{~g} / 1 \mathrm{HBc} \Delta-5 \mathrm{~L}$ protein was adsorbed onto carbon-coated copper 400-mesh electron microscopy grids for 2-3 min, and negatively stained with $20 \mathrm{~g} / \mathrm{l}$ uranyl acetate. Grids were examined with a Hitachi H 7650 transmission electron microscope (TEM) at $80 \mathrm{kV}$.

PBMC culture. Dendritic cells (DCs) were generated as described with some modifications (26). Briefly, PBMC were cultured in RPMI-1640 medium containing 10\% FCS for $2 \mathrm{~h}$ at $37^{\circ} \mathrm{C}$. Adherent cells were cultured for 6 days in RPMI-1640 medium containing 10\% FCS, $1000 \mathrm{U} / \mathrm{ml}$ human GM-CSF (Peprotech Inc., NJ, USA) and 500 U/ml human IL-4 (Peprotech Inc.). Culture medium and cytokines were refreshed every other day. On day 7 of culture, $10 \mathrm{ng} / \mathrm{ml}$ tumor necrosis factor- $\alpha$ (TNF- $\alpha$, Peprotech Inc.) was added for the maturation of DCs. 


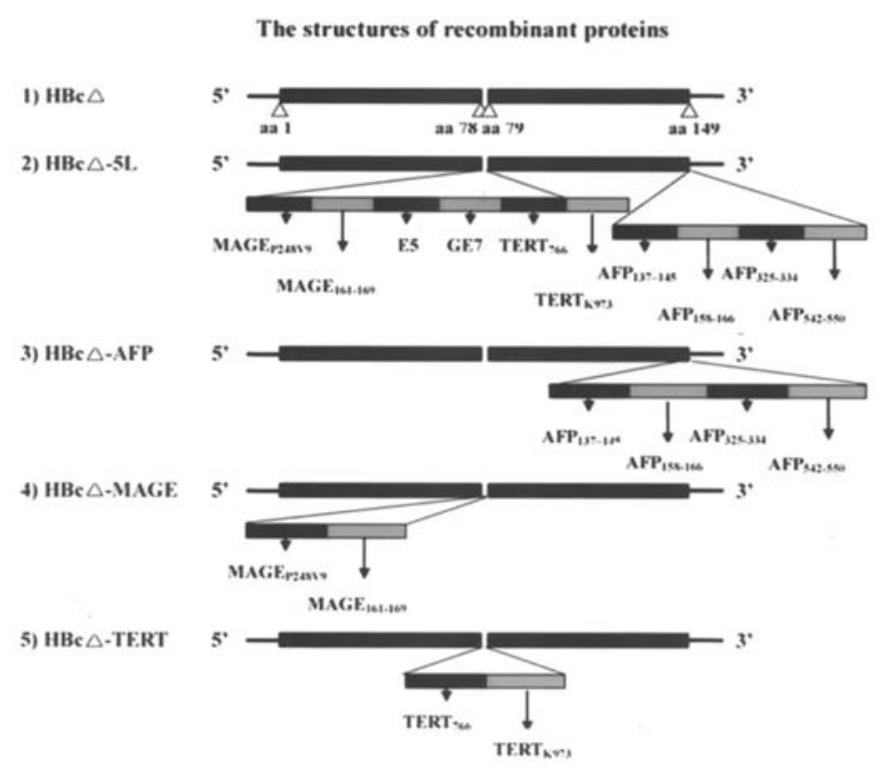

Figure 1. Scheme of representation of the structure of 4 recombinant proteins.

After $72 \mathrm{~h}$ maturation, autologous DCs were pulsed with peptide for $3 \mathrm{~h}$. PBMC from donors were plated at a concentration of $5 \times 10^{6}$ cells per well in a 24 -well culture plate and stimulated with peptide at a concentration of $20 \mu \mathrm{g} / \mathrm{ml}$ on day 0 and with $1 \times 10^{7}$ peptide-pulsed autologous DCs on day 7. rhIL-2 (100 IU/ml) (Chiron, Emeryville, CA, USA) was added to the culture every other day and the cells were cultured for 14 days.

Detection of peptide-specific CTL in vitro. Target cell lysis was determined using a lactate dehydrogenase (LDH)-release assay (Promega, Madison, WI, USA) according to the manufacturer's instructions. Two-week peptide-sensitized PBMC were used as effector cells and SMMC-7721 was used as target cells in the cytotoxicity assay. And L-02 cells were used as control. Briefly, target cells $\left(5 \times 10^{4}\right.$ cells/well $)$ were cocultured with effector cells at different ratios of 1:15, 1:30 and 1:60 in a 96-well round-bottomed culture plate. Each experiment was carried out in triplicate and at least twice, and the average value was used to determine the percentage of viability. The percentage of target cell lysis was calculated by using the following formula: Percent cytotoxicity = (Experimental - Culture medium background)/(Maximum LDH release - Culture medium background) x 100. Maximum LDH release obtained by adding lysis solution (90 g/l Triton X-100) at the recommended dilution to target cells.

IFN- $\gamma$ ELISPOT assay. Peptide-specific reactivity of PBMC was assessed by standard IFN- $\gamma$ ELISPOT (MABtech, Nacha, Sweden). Briefly, a 96-well filter plate was precoated with $1.5 \mu \mathrm{g} /$ well anti-human IFN- $\gamma$ monoclonal antibody. Two-week peptide-sensitized PBMC $\left(1 \times 10^{4} /\right.$ well $)$ as effector cells and irradiated SMMC-7721 cells $\left(5 \times 10^{3} /\right.$ well $)$ as target cells were transferred to ELISPOT plate and incubated for $16 \mathrm{~h}$ at $37^{\circ} \mathrm{C}$. L-02 cells were used as control. The plates were then washed and incubated with $100 \mu \mathrm{l} 1 \mu \mathrm{g} / \mathrm{ml}$ biotin labeling antibody and then conjugated with $100 \mu 1$ second alkaline phosphatase labeled antibody (1:1000 dilution). NBT/BCIP-plus reagent
(100 $\mu$ l) was then used to colorize bound IFN- $\gamma$, forming visualized spots. The colored spots, representing cytokine producing cells, were counted under a dissecting microscope.

Serologic test. Six-week-old BALB/c mice were immunized subcutaneouly on week 0,3 and 6 , with $10 \mu \mathrm{g}$ of $\mathrm{HBc} \Delta-5 \mathrm{~L}$ or $10 \mu \mathrm{g}$ of $\mathrm{HBc} \Delta$ or $100 \mu \mathrm{l}$ PBS $(\mathrm{n}=10)$. On week 3, 5, 7 and 9 , blood samples were collected from mice and stored at $-20^{\circ} \mathrm{C}$ for further assay. The levels of specific antibodies of sera of immunized mice against $\mathrm{HBc} \Delta-5 \mathrm{~L}$ were identified by sandwich ELISA. Briefly, 96-well plates were prepared with IGF-I $(0.1 \mu \mathrm{g} /$ well $)$. Sera samples of mice were added and incubated on the plates at $37^{\circ} \mathrm{C}$ for $1 \mathrm{~h}$ at 2-fold dilution. Goat anti-mouse HRP-labelled IgG (Sigma) were added at $37^{\circ} \mathrm{C}$ for $1 \mathrm{~h}$. And the plates were subsequently detected by TMB substrate. Absorbance was measured with a plate reader at $450 \mathrm{~nm}$. An OD value $\geq 2.1$ times that of negative control was considered positive. To detect the specificity of antibody, sera samples were incubated with $\mathrm{HBcAb}-\mathrm{HRP}$ and $\mathrm{HBeAb}-\mathrm{HRP}$ on $\mathrm{HBc}$ coated plates at $37^{\circ} \mathrm{C}$ for $1 \mathrm{~h}$ and detected by TMB substrate by competitive ELISA. All assays were performed in duplicate. The wells with only added HBcAb-HRP or HBeAb-HRP were negative control. Inhibitory rate $(\%)=$ (negative control $\mathrm{A}_{450}$-test $\mathrm{A}_{450}$ )/negative control $\mathrm{A}_{450} \times 100$. Inhibitory rate $\geq 50 \%$ was considered positive.

MTT assay. SMMC-7721 cells were plated in 24-well plates with $2 \times 10^{4} /$ well in regular growth medium. Then cells were switched to serum-free media for $24 \mathrm{~h}$, the incubation was continued in the absence (control) or presence of anti-HBc $\Delta$ $5 \mathrm{~L}$ or anti-HBc $\Delta$ sera (1:200 dilution) at $37^{\circ} \mathrm{C}$ for $12,24,48$ and $72 \mathrm{~h}$. In some experiments, growth was induced by IGF-I $(10 \mathrm{ng} / \mathrm{ml})$ in the absence or presence of sera at $37^{\circ} \mathrm{C}$ for 24 h. L-02 cells were used as control. All treatments were done in triplicates. Growth was assayed by the 3-(4,5-dimethylthiazol-2-yl)-2,5-diphenyltetrazolium bromide (MTT) assay as described previously (27). In all experiments, the reaction was terminated by adding a total of $60 \mu \mathrm{l}$ of $5 \mathrm{mg} / \mathrm{ml}$ stock of MTT solution in PBS to each well. After incubation for $4 \mathrm{~h}$ at $37^{\circ} \mathrm{C}$, wells were aspirated and formazan crystals were lysed with $200 \mu 1 \mathrm{DMSO}$. Absorbance was measured with a plate reader at $570 \mathrm{~nm}$ using a $670-\mathrm{nm}$ differential filter. Inhibitory rate $(\%)=\left(1\right.$-test $\mathrm{A}_{570} /$ control $\left.\mathrm{A}_{570}\right) \times 100$.

Statistical analysis. All results were expressed as mean \pm SD. Statistical differences between groups were determined by using Student's t-test. Differences were considered statistically when $\mathrm{P}<0.05$.

\section{Results}

Expression and purification and identification of recombinant proteins in E. coli. Verification of pET-HBc $\Delta-5 \mathrm{~L}$, pET-HBc $\Delta$-AFP, pET-HBc $\Delta$-MAGE and pET-HBc $\Delta$-TERT constructs was done by enzyme restricting and sequencing analyses. The schemes of four recombinant proteins are illustrated in Fig. 1. E. coli BL21 (DE3) cells harboring the plasmids expressing four recombinant proteins were stimulated by incubation with IPTG for $5 \mathrm{~h}$. Cells were harvested, and lyzed in SDS sample buffer and examined for the production 


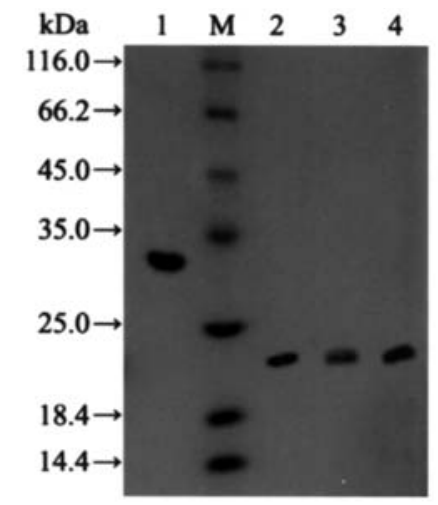

Figure 2. SDS-PAGE analysis of the purified 4 recombinant proteins. Proteins were separated by $12 \%$ SDS-PAGE gel and revealed by coomassie brilliant blue staining. Lane 1, purified protein $\mathrm{HBc} \Delta-5 \mathrm{~L}$; lane 2, purified protein $\mathrm{HBc} \Delta-\mathrm{AFP}$; lane 3, purified protein $\mathrm{HBc} \Delta$-MAGE; lane 4, purified protein $\mathrm{HBc} \Delta$-TERT; lane M, protein molecular weight markers.

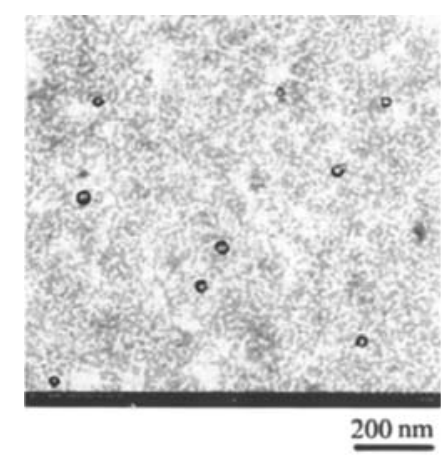

Figure 3. Electron microscopic image of particles formed by $\mathrm{HBc} \Delta-5 \mathrm{~L}$. The particles were negatively stained with $20 \mathrm{~g} / 1$ uranyl acetate. $\mathrm{HBc} \Delta-5 \mathrm{~L}$ particles appear as uniform particles with a diameter of $30 \mathrm{~nm}$. Scale bar, $200 \mathrm{~nm}$.

of aimed proteins on SDS-PAGE (Fig. 2). Recombinant proteins were observed at $30 \mathrm{kDa}(\mathrm{HBc} \Delta-5 \mathrm{~L}), 22 \mathrm{kDa}(\mathrm{HBc} \Delta-\mathrm{AFP})$, $21 \mathrm{kDa}(\mathrm{HBc} \Delta$-MAGE) and $21 \mathrm{kDa}(\mathrm{HBc} \Delta$-MAGE). After purification as described previously (7), the purified protein migrated as a single protein band on SDS-PAGE and possessed a high degree of purity.

The electron microscope image of $H B c \Delta-5 L$ particles. The fine structures of $\mathrm{HBc} \Delta$ particles which could accept longlength insertion and undergo correct folding were revealed by electron microscopy (Fig. 3). When $\operatorname{HBc} \Delta-5 \mathrm{~L}$ was analyzed by TEM, the presence of spherical particles with uniform morphology and size distribution were observed. The mean diameter of particles was $30 \mathrm{~nm}$.

Detection of expression of three HCC TAAs of HBcA-5L. To detect the expression of three HCC TAAs (AFP, MAGE and TERT), PBMC from HCC patients $(\mathrm{n}=8)$ were stimulated in vitro with three recombinant proteins $(\mathrm{HBc} \Delta-\mathrm{AFP}, \mathrm{HBc} \Delta$ MAGE, HBc $\Delta$-TERT), respectively. Following stimulation, effector cells (PBMC) were co-cultured with target cells (SMMC-7721) $\left(\mathrm{AFP}^{+}, \mathrm{MAGE}^{+} \mathrm{A}^{+}, \mathrm{TERT}^{+}\right)$by measurement of the release of LDH. LDH release assay indicated that these three proteins can induce PBMC from HCC donors of

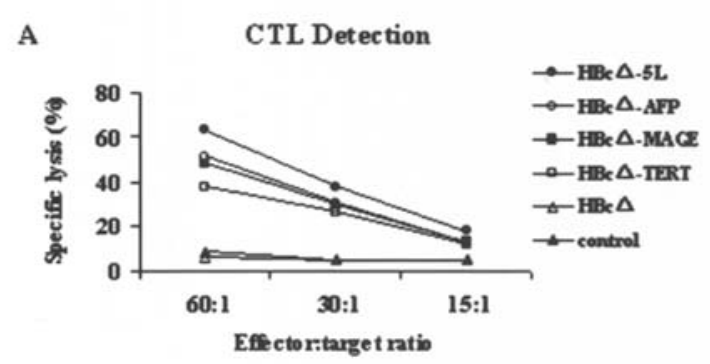

B

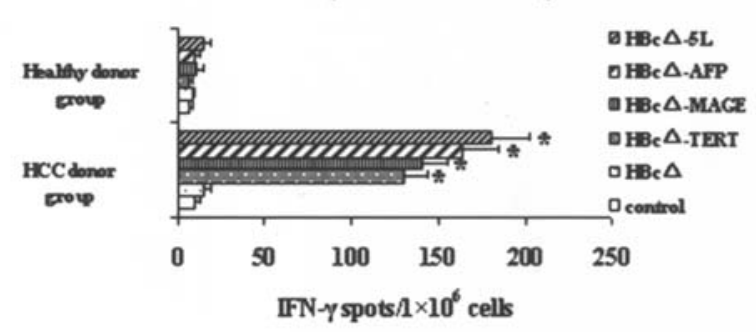

Figure 4. $\mathrm{HBc} \Delta-5 \mathrm{~L}$ induction of specific CTL responses and the production of IFN- $\gamma$. (A) PBMC from HCC donors group had cytotoxic activity against target cells (SMMC-7721) endogenously expressing the three antigens. Expanded effector PBMC were co-cultured at the indicated effector:target (E:T) cell ratio. Target cell lysis was quantitated using an $\mathrm{LDH}$ release assay. Entries represente mean values of three replicate cytotoxicity assay cultures. (B) IFN- $\gamma$ ELISPOT assay. IFN- $\gamma$ secreting PBMC from donors were measured using an ELISPOT assay after re-stimulation in vitro with target cells. The mean number of spot-forming cells per $10^{6}$ cells is shown. Results are given as means $\pm \mathrm{SD}$. ${ }^{*} \mathrm{P}<0.05$ vs. control.

specific cytotoxicity on target cells (Fig. 4A). The ELISPOT assay revealed that the activated PBMC from HCC donor were markedly increased in contrast to control $(\mathrm{P}<0.05)$ (Fig. 4B).

Tumor-specific CTL activity and IFN- $\gamma$ ELISPOT assay stimulated by $H B C \Delta-5 L$. To determine whether the CTL epitopes of protein $\mathrm{HBc} \Delta-5 \mathrm{~L}$ could induce a specific CTL response, PBMC from HCC patients $(\mathrm{n}=8)$ were stimulated in vitro with $\mathrm{HBc} \Delta-5 \mathrm{~L}$ protein. Following stimulation, cells were seeded at $60: 1,30: 1$ and 15:1 $\mathrm{E} / \mathrm{T}$ ratios by measure of the release of LDH (Promega). The data in Fig. 4A show the cytotoxic activities generated in PBMC after restimulation with $\operatorname{HBc} \Delta-5 \mathrm{~L}$. LDH release and target cell lysis by cytotoxic $\mathrm{T}$ cells demonstrated a significant correlation. This assay demonstrated only low level (5\% or less) of PBMC of healthy donor CTL activation. This finding was likely due to a spontaneous leakage of granular contents from a minor population of activated PBMC. Taken together, these results established the $\operatorname{HBc} \Delta-5 \mathrm{~L}$ protein induced potent specific cytotoxic T cell responses in PBMC of the HCC donor group.

To determine the frequency of IFN- $\gamma$-secreting PBMC that were capable of responding to a TAA, we performed an IFN $-\gamma$ ELISPOT assay (Fig. 4B). The number of IFN $-\gamma$ positive spots of HCC patient group were $180 \pm 22$ spots per $10^{6}$ cells in the $\mathrm{HBc} \Delta-5 \mathrm{~L}$ group, compared to $15 \pm 4$ spots per $10^{6}$ cells in the healthy donor group $(\mathrm{P}<0.05)$.

$H B c \Delta-5 L$ elicited mice generating specific antibodies. To identify the levels of antibodies against $\operatorname{HBc} \Delta-5 \mathrm{~L}$ after vacci- 


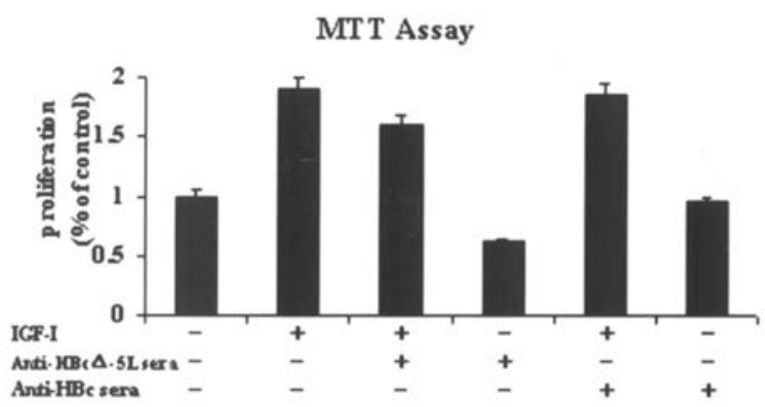

Figure 5. Effects of sera from $\mathrm{HBc} \Delta-5 \mathrm{~L}$ and $\mathrm{HBc} \Delta$ carrier vaccination groups on the proliferation of SMMC-7721 cells. Cells were incubated with $10 \mathrm{ng} / \mathrm{ml}$ IGF-I in the absence or presence of sera for $24 \mathrm{~h}$. Control incubations contained neither IGF-I nor sera. Cellular growth was determined by MTT assay.

nation, sera from immunized mice were detected by ELISA. Results show that the positive rate of anti-IGF-I antibodies from sera of $\operatorname{HBc} \Delta-5 \mathrm{~L}$ vaccination group was $100 \%$. Specific antibody titers increased along with vaccination, and the peak titer $\left(1: 10^{5}\right)$ was on week 7 then declined in week 9. The titer of sera of $\mathrm{HBc} \Delta$ control group was 1:200 $(\mathrm{P}<0.05$, contrast to $\mathrm{HBc} \Delta-5 \mathrm{~L}$ vaccination group). $\mathrm{HBcAb}$ and $\mathrm{HBe} A b$ titers $(1: 256-1: 1024)$ were determined in sera of mice immunized with $\mathrm{HBc} \Delta-5 \mathrm{~L}$ by ELISA and were an order of magnitude lower than those obtained in mice immunized with $\mathrm{HBc} \Delta$ carrier $\left(1: 10^{6}\right)(\mathrm{P}<0.05)$. Sera from PBS control mice did not show reactivity against IGF-I and HBc (less 1:200).

Anti-HBc $\Delta-5 L$ sera inhibited the proliferation of SMMC-7721 cells. To elucidate the mechanism of action of sera from $\mathrm{HBc} \Delta-5 \mathrm{~L}$ vaccination group on the induction of terminal differentiation, we examined, by MTT assay, the effect on cell growth without additional IGF-I (Fig. 5). Sera from $\mathrm{HBc} \Delta-5 \mathrm{~L}$ vaccination group (1:200 dilution) exhibited $\sim 42 \%$ inhibition of SMMC-7721 proliferation at $24 \mathrm{~h}$ and remained at that level during the rest of the experimental period $(72 \mathrm{~h})$, and had little inhibitory effects on L-02 cells (data not shown). To determine whether sera from $\mathrm{HBc} \Delta-5 \mathrm{~L}$ vaccination group could inhibit IGF-I-induced growth of SMMC-7721 cells, $24 \mathrm{~h}$ serum-starved cells were incubated with sera in the presence of $10 \mathrm{ng} / \mathrm{ml} \mathrm{IGF-I} \mathrm{for} 24 \mathrm{~h}$. As expected, IGF-I caused 2-fold stimulation of growth of SMMC-7721 cells over the controls. Interestingly, this stimulation was indeed attenuated by sera (1:200 dilution). In fact, in the presence of sera, there was $\sim 60 \%$ proliferation of cell growth compared with the controls. Control sera against $\mathrm{HBc} \Delta$ carrier had little inhibitory effect against SMMC-7721 or L-02 cells.

\section{Discussion}

In this study, we constructed the $\operatorname{HBc} \Delta$ carrier, to which multiple CTL and Th epitopes of HCC TAAs and ligands for EGFR and IGFR was inserted, designed $\mathrm{HBc} \Delta-5 \mathrm{~L}$, targeting cellular and humoral immune responses and inducing antitumor effect against $\mathrm{HCC}$ cells. The recombinant $\mathrm{HBc}$ particles as carrier have been used to display immunodominant epitopes of virus, bacterial as well as protozoan protein (28-30), but no data are available of TAAs. Anti- tumor immunotherapeutic applicability of the $\mathrm{HBc}$ particle as carrier has not been reported until now.

Herein, we showed for the first time the $\mathrm{HBc}$ particle as carrier to display multiple HCC TAAs eliciting robust cellular and humoral tumor-specific immune response. Enhancement of the natural immune response was demonstrated by in vitro cell-mediated cytotoxicity assays. Firstly, we tested specific responses against tumor cells of three recombinant proteins ( $\mathrm{HBc} \Delta$-AFP, $\mathrm{HBc} \Delta$-MAGE, $\mathrm{HBc} \Delta$ TERT) inducing PBMC from HCC donor. Cytotoxic assays showed the ability of $\mathrm{HBc} \Delta-5 \mathrm{~L}$ to induce potent $\mathrm{CTL}$ reactions of PBMC of HCC donor group in vitro (E:T=60:1, 62.7\% specific lysis). This was supported in our study by the observations that $\mathrm{HBc} \Delta-5 \mathrm{~L}$ significantly enhanced IFN- $\gamma$ production and had the ability to induce potent anti-tumor responses. Sera from immunized mice were used to evaluate the immunogenicity of $\mathrm{HBc} \Delta-5 \mathrm{~L}$, its specific antibody titer was extremely high (up to $1: 10^{5}$ ). These results suggested that $\mathrm{HBc} \Delta-5 \mathrm{~L}$ induced specific anti-tumor cellular and humoral immune responses and supported its potential application in the clinical setting.

Our results pointed out special applications of the $\mathrm{HBc}$ particle as the TAAs epitope carrier. Important practical advantage of the $\mathrm{HBc}$ model consisted in the fact that chimeric HBc-derived particles were easy to purity. Our study used denatured acrylamide gel purification, making dissociation with subsequent re-association easier. Additionally, the use of $\mathrm{HBc}$ particle as carrier could prove capable of ensuring a high level of $\mathrm{B}$ cell and $\mathrm{T}$ cell foreign epitope immunogenicity. For example, our previous data indicated that $\mathrm{HBc}$ particle was effective in construction of the DNA vaccine against Taenia solium cysticercosis, the protective rate of this vaccine was exciting (7). The use of the $\mathrm{HBc}$ carrier may provide both T-cell-dependent and T-cellindependent character of the immune responses to inserted epitopes (31). It is important to note that the aimed protein $\mathrm{HBc} \Delta-5 \mathrm{~L}$ was successfully expressed in E. coli and reassociated mosaic particles (Fig. 3). Foreign peptides aligned with the selected sites of $\mathrm{HBc} \Delta$ particles. High-density display of the foreign peptides played an extremely important role in inducing immune responses. In addition, insertion of foreign sequences internally within $\mathrm{HBc}$, at MIR, which had previously been suggested to represent a dominant antibody binding region, drastically decreased the antigenicity and immunogenicity of $\mathrm{HBc}(32)$. Therefore, $\mathrm{HBc} \Delta-5 \mathrm{~L}$ could also induce promising effects in future clinical trials even in $\mathrm{HBc}$ positive HCC patients.

$\mathrm{LDH}$ release assay showed that the specific cytotoxic activities generated in PBMC after restimulation with $\mathrm{HBc} \Delta$ $5 \mathrm{~L}$. LDH release assay is commonly used for testing cytotoxicity of various experimental compounds by measurement of the leakage of components from the cytoplasm into the surrounding culture medium. This technology has been demonstrated to be identical to values determined in parallel ${ }^{51} \mathrm{Cr}$ release assays $(33,34)$. Because IFN $-\gamma$ has been recognized as a critical cytokine involved in effective anti-tumor immune responses, the production of this cytokine in response to epitope-specific stimulation is critical for $\mathrm{T}$ cell-mediated tumor regression $(35,36)$. We used IFN- $\gamma$ ELISPOT assay to detect the activated PBMC. In 
contrast to the $\mathrm{HBc}$ carrier, re-stimulated with $\mathrm{HBc} \Delta-5 \mathrm{~L}$, IFN- $\gamma$ secretion was significantly enhanced.

Because the combination of cellular and humoral immune responses has better protection from tumor challenge, where the absence of either the cellular or humoral arm leads to incomplete protection $(37,38)$. We extended our studies to an analysis of humoral immune responses. Data demonstrated that protein $\mathrm{HBc} \Delta-5 \mathrm{~L}$ was capable of eliciting specific antibodies in immunized mice. For analysis of anti-HBc $\Delta-5 \mathrm{~L}$ sera inhibitory effects on the proliferation of HCC cells, cells were incubated with sera in the presence of IGF-I. Interestingly, this stimulation was indeed attenuated by sera. The results confirmed that specific antibodies against ligands elicited by $\mathrm{HBc} \Delta-5 \mathrm{~L}$ had an inhibitory role on HCC cells.

In conclusion, our data indicate an application of $\mathrm{HBc}$ particle as carrier in an immunotherapeutic approache against HCC. We showed that the polyepitopic peptide $\mathrm{HBc} \Delta-5 \mathrm{~L}$ had the ability to induce tumor-specific humoral and cellular immune responses. The recombinant $\mathrm{HBc}$ particles may prove to be a suitable carrier on the display of TAAs. The clinical benefit remains to be established in future clinical trials. This study established the foundation for further optimization and refinements of the therapy strategy of cellular and humoral combination immunity with the ultimate goal of developing therapeutic methods for HCC patients.

\section{Acknowledgements}

This study was supported in part by grants from the Natural Science Foundation of Jiangsu province, China (BK2005004), and the Tenth Five-Year Scientific Project of Jiangsu province, China (BK2004011).

\section{References}

1. Bain I and McMaster P: Benign and malignant liver tumours. Surgery 15: 169-174, 1997.

2. Duvoux C: Epidemiology and diagnosis of HCC in cirrhosis. Ann Chir 52: 511-517, 1998.

3. Badvie S: Hepatocellular carcinoma. Postgrad Med J 76: 4-11, 2000.

4. Lin SM, Lin CJ, Lin CC, Hsu CW and Chen YC: Randomised controlled trial comparing percutaneous radiofrequency thermal ablation, percutaneous ethanol injection and percutaneous acetic acid injection to treat hepatocellular carcinoma of $3 \mathrm{~cm}$ or less. Gut 54: 1151-1156, 2005.

5. Greten TF and Jaffee EM: Cancer vaccines. J Clin Oncol 17: 1047-1060, 1999.

6. Bottcher B, Wynne SA and Crowther RA: Determination of the fold of the core protein of hepatitis B virus by electron cryomicroscopy. Nature 386: 88-91, 1997.

7. Wu L, Diao Z, Deng X, Gao J, Zhou Z, Liu Y and Wang Y: DNA vaccine against Taenia solium cysticercosis expressed as a modified hepatitis B virus core particle containing three epitopes shared by Taenia crassiceps and Taenia solium. J Nanosci Nanotechnol 5: 1204-1210, 2005.

8. Borisova G, Arya B, Dislers A, Borschukova O, Tsibinogin V, Skrastina D, Eldarov MA, Pumpens P, Skryabin KG and Grens E: Hybrid hepatitis B virus nucleocapsid bearing an immunodominant region from hepatitis B virus surface antigen. J Virol 67: 3696-3701, 1993.

9. Fehr T, Skrastina D, Pumpens P and Zinkernagel RM: T cellindependent type I antibody response against $\mathrm{B}$ cell epitopes expressed repetitively on recombinant virus particles. Proc Natl Acad Sci USA 95: 9477-9481, 1998.

10. Vollmer CM Jr, Eilber FC, Butterfield LH, Ribas A, Dissette VB, Koh A, Montejo LD, Lee MC, Andrews KJ, McBride WH, Glaspy JA and Economou JS: Alpha-fetoprotein-specific genetic immunotherapy for hepatocellular carcinoma. Cancer Res 59: 3064-3067, 1999 .
11. Butterfield LH, Meng WS, Koh A, Vollmer CM, Ribas A, Dissette VB, Faull K, Glaspy JA, McBride WH and Economou JS: T cell responses to HLA-A*0201-restricted peptides derived from human alpha fetoprotein. J Immunol 166: 5300-5308, 2001.

12. Zerbini A, Pilli M, Soliani P, Ziegler S, Pelosi G, Orlandini A, Cavallo C, Uggeri J, Scandroglio R, Crafa P, Spagnoli GC, Ferrari $\mathrm{C}$ and Missale G: Ex vivo characterization of tumorderived melanoma antigen encoding gene-specific $\mathrm{CD} 8^{+}$cells in patients with hepatocellular carcinoma. J Hepatol 40: 102-109, 2004.

13. Graff-Dubois S, Faure O, Gross DA, Alves P, Scardino A, Chouaib S, Lemonnier FA and Kosmatopoulos K: Generation of CTL recognizing an HLA-A*0201-restricted epitope shared by MAGE-A1,-A2,-A3, -A4, -A6,-A10 and -A12 tumor antigens: implication in a broad-spectrum tumor immunotherapy. J Immunol 169: 575-580, 2002.

14. Liu G, Ying H, Zeng G, Wheeler CJ, Black KL and Yu JS: HER-2, gp100 and MAGE-1 are expressed in human glioblastoma and recognized by cytotoxic $\mathrm{T}$ cells. Cancer Res 64: 4980-4986, 2004

15. Huang Q, Zhang X, Wang H, Yan B, Kirkpatrick J, Dewhrist MW and Li CY: A novel conditionally replicative adenovirus vector targeting telomerase-positive tumor cells. Clin Cancer Res 10: $1439-1445,2004$

16. Gorbunova V, Seluanov A and Pereira-Smith OM: Evidence that high telomerase activity may induce a senescent-like growth arrest in human fibroblasts. J Biol Chem 278: 7692-7698, 2003.

17. Schroers R, Shen L, Rollins L, Rooney CM, Slawin K, Sonderstrup G, Huang XF and Chen SY: Human telomerase reverse transcriptase-specific T-helper responses induced by promiscuous major histocompatibility complex class II-restricted epitopes. Clin Cancer Res 9: 4743-4755, 2003.

18. Vonderheide RH, Anderson KS, Hahn WC, Butler MO, Schultze JL and Nadler LM: Characterization of HLA-A3restricted cytotoxic $\mathrm{T}$ lymphocytes reactive against the widely expressed tumor antigen telomerase. Clin Cancer Res 7: 3343-3348, 2001.

19. Adjei AA and Hidalgo M: Intracellular signal transduction pathway proteins as targets for cancer therapy. J Clin Oncol 23: 5386-5403, 2005.

20. Rowinsky EK: Signal events: cell signal transduction and its inhibition in cancer. Oncologist 8: 5-17, 2003.

21. Ren C, Li J and Zhao R: In vitro and in vivo experiment of transduction of reporter gene into tumors by E5 gene delivery system. Zhonghua Yi Xue Za Zhi 81: 1113-1117, 2001.

22. Liu X, Tian P, Yu Y, Yao M, Cao X and Gu J: Enhanced antitumor effect of EGF R-targeted p21WAF-1 and GM-CSF gene transfer in the established murine hepatoma by peritumoral injection. Cancer Gene Ther 9: 100-108, 2002.

23. Wang YS, Ma XL, Qi TG, Liu XD, Meng YS and Guan GJ: Downregulation of alpha-fetoprotein siRNA inhibits proliferation of SMMC-7721 cells. World J Gastroenterol 11: 6053-6055, 2005.

24. Xiao J, Chen HS, Fei R, Cong X, Wang LP, Wang Y, Jiang D, Wei $L$ and Wang Y: Expression of MAGE-A1 mRNA is associated with gene hypomethylation in hepatocarcinoma cell lines. J Gastroenterol 40: 716-721, 2005.

25. Du QY, Wang XB, Chen XJ, Zheng W and Wang SQ: Antitumor mechanism of antisense cantide targeting human telomerase reverse transcriptase. World J Gastroenterol 9: 2030-2035, 2003.

26. Liu KJ, Wang CC, Chen LT, Cheng AL, Lin DT, Wu YC, Yu WL, Hung YM, Yang HY, Juang SH and Whang-Peng J: Generation of carcinoembryonic antigen (CEA)-specific T-cell responses in HLA-A*0201 and HLA-A*2402 late-stage colo-rectal cancer patients after vaccination with dendritic cells loaded with CEA peptides. Clin Cancer Res 10: 2645-2651, 2004.

27. Twentyman PR and Luscombe M: A study of some variables in a tetrazolium dye (MTT) based assay for cell growth and chemosensitivity. Br J Cancer 56: 279-285, 1987.

28. Schodel F, Peterson D, Hughes J, Wirtz R and Milich D: Hybrid hepatitis B virus core antigen as a vaccine carrier moiety: I. presentation of foreign epitopes. J Biotechnol 44: 91-96, 1996.

29. Schodel F, Kelly S, Tinge S, Hopkins S, Peterson D, Milich D and Curtiss R III: Hybrid hepatitis B virus core antigen as a vaccine carrier moiety. II. Expression in avirulent Salmonella spp. for mucosal immunization. Adv Exp Med Biol 397: 15-21, 1996.

30. Murray K and Shiau AL: The core antigen of hepatitis B virus as a carrier for immunogenic peptides. Biol Chem 380: 277-283, 1999. 
31. Milich DR and McLachlan A: The nucleocapsid of hepatitis B virus is both a T-cell-independent and a T-cell-dependent antigen. Science 234: 1398-1401, 1986.

32. Schodel F, Moriarty AM, Peterson DL, Zheng JA, Hughes JL, Will H, Leturcq DJ, McGee JS and Milich DR: The position of heterologous epitopes inserted in hepatitis B virus core particles determines their immunogenicity. J Virol 66: 106-114, 1992.

33. Korzeniewski $C$ and Callewaert DM: An enzyme-release assay for natural cytotoxicity. J Immunol Methods 64: 313-320, 1983.

34. Decker T and Lohmann-Matthes ML: A quick and simple method for the quantitation of lactate dehydrogenase release in measurements of cellular cytotoxicity and tumor necrosis factor (TNF) activity. J Immunol Methods 115: 61-69, 1988.

35. Boehm U, Klamp T, Groot M and Howard JC: Cellular responses to interferon-gamma. Annu Rev Immunol 15: 749-795, 1997.
36. Kammula US, Marincola FM and Rosenberg SA: Real-time quantitative polymerase chain reaction assessment of immune reactivity in melanoma patients after tumor peptide vaccination. J Natl Cancer Inst 92: 1336-1344, 2000.

37. Dakappagari NK, Pyles J, Parihar R, Carson WE, Young DC and Kaumaya PT: A chimeric multi-human epidermal growth factor receptor-2 B cell epitope peptide vaccine mediates superior antitumor responses. J Immunol 170: 4242-4253, 2003.

38. Reilly RT, Machiels JP, Emens LA, Ercolini AM, Okoye FI, Lei RY, Weintraub D and Jaffee EM: The collaboration of both humoral and cellular HER-2/neu-targeted immune responses is required for the complete eradication of HER-2/neu-expressing tumors. Cancer Res 61: 880-883, 2001. 